\title{
Student use of Facebook groups as a support for academic learning
}

\author{
Janet A. Orioque* \\ College of Graduate Studies, Palompon Institute of Technology, Palompon Leyte, \\ Philippines
}

\begin{abstract}
This main objective of this study was to discover how Facebook groups use impact the academic learning of undergraduate students. This paper applied a mixed research method in which the quantitative as core and the qualitative is supplemental. Data from a sample of 590 college students are used to analyze how Facebook groups use, ease, usefulness, and academic performance related to positive and negative correlation among students. It shows a significant relationship between the Facebook groups' use with ease of use, the usefulness of Facebook groups, and academic performance. Qualitative results suggest that using Facebook groups facilitates the students' academic learning as it shows their satisfactory academic performance.
\end{abstract}

Keywords: Facebook groups, Ease, Usefulness, Collaborative learning, Academic performance.

\section{INTRODUCTION}

Facebook is the biggest social media platform globally, and it is one of the most

\section{OPEN ACCESS}

Received: January 22, 2021

Revised: March 26, 2021

Accepted: April 9, 2021

Corresponding Author:

Janet A. Orioque

janet.orioque@pit.edu.ph

Copyright: The Author(s). This is an open access article distributed under the terms of the Creative Commons Attribution License (CC BY 4.0), which permits unrestricted distribution provided the original author and source are cited.

\section{Publisher:}

Chaoyang University of

Technology

ISSN: 1727-2394 (Print)

ISSN: 1727-7841 (Online) popular Web applications within the past decade that have over 2 billion users around the world (Statista, 2018). It has extraordinary popularity among undergraduate college students in their academic and social life. College students' Facebook users were seventy to ninety percent (Dahlstrom et al., 2011). Facebook gives a wide variety of features for editing walls, providing comments, perusing the news feed, giving likes, forming groups, playing diversions fan pages, making occasions, taking notes, and chatting in groups (Tracii and Xenos, 2011). One of the features of Facebook is the easy formation of groups of people.

Nowadays, schools and institutions encounter numerous innovative headways and changes procedures in improving their instructing techniques to satisfy their students' emerging demands. Some schools utilized online media as a learning tool (Abecia et al., 2014). Subsequently, scholarly exercises in institutions and professors carry out progressively through social media; for example, Facebook, Twitter, and Linkedln. These are used to communicate with current and potential students and convey instructional content (Ainin et al., 2015). Also, another paper was conducted to comprehend the social aspects of Facebook groups use among students and how they perceived utilizing it for academic purposes. It was an exploratory survey appropriated to 105 students at a large university in Malaysia. It revealed that the students' view of utilizing Facebook for academic purposes was not significantly related to study habits and students' involvement (Yang et al., 2011).

Yang et al. (2011) asserted that after doing a thorough literature review, it is essential to conduct a more empirical study on using Facebook groups as an academic tool. Further, Nguyen et al. (2013) stressed that, notwithstanding numerous studies on Facebook groups, there had been an absence of intensive research on this online platform as an educational tool among college students. To shed light on this topic, this study aimed to highlight the impact of using Facebook groups for academic learning among 
Orioque et al., International Journal of Applied Science and Engineering, 18(4), 2021021

undergraduate students.

Three research questions guide this study: 1) How do college students perceive the use of Facebook groups for academic learning? Does it facilitate or impede academic learning? 2) Does Facebook groups' use for academic learning significantly impact students' academic performance? 3) Do the correlation exist among Facebook groups use, perceived usefulness, ease of use and academic performance? The rest of the paper is organized as follows: The first section, literature review, theoretical model, and hypothesis development. In the second section, methods and procedures of data collection, measures, statistical treatment of data are introduced. In the third section, results and discussions are presented. In the fourth section, the interpretation of the findings of the study is provided. Lastly, conclusions, limitations, contributions, and recommendations are discussed.

\subsection{Literature Review}

\subsubsection{Facebook Educational Usage}

Universities today act as academic institutions that train students to become the next generation of researchers, but they also serve a number of additional roles. To be more specific, social functions become an integral part of university education, achieving one of the institution's primary goals is effective student education. Universities and educational institutions are concerned about enhancing university students' disinterest in the traditional way of learning, which calls into question the teaching experience of a teacher who uses it. As a result, if professors are to effectively adopt the modern method of occupying their student's attention, they must be "entertainers" who involve students in their course content entirety. And in that endeavor, posting different content on a social network where students can easily access and use learning materials dramatically aids them in achieving academic performance at the individual level (Manasijevic et al., 2016).

Students must learn new skills and rapidly adjust to the university culture of life since they are in the transition period as they enroll in a university. Some of these abilities are academic, such as learning how to participate in increasingly complex academic work levels. Students graduating from high school to college must first learn to control their time to meet their college operational duties (Dickie and Meier, 2015; Junco, 2015).

Using the numerous advantages of Facebook, students and professors can share a variety of tools, both amusing and instructional, such as materials and multimedia images, as well as extensive range of diagrams that can significantly aid the traditional methods of learning (Qureshiet al., 2014; Sanchez et al., 2014).

Sanchez et al. (2014) evaluated how Facebook could be used for educational purposes. They used structural equation modelling to investigate the connections between Facebook adoption, user goals, and educational use. Their findings indicate three fundamental structures of Facebook educational use that can be defined as communication, collaboration, and resource/material sharing.

According to Manasijevic et al. (2016), communication involves activities such as communication between students and their instructors, facilitating class discussions, following announcements about classes and courses, departments or colleges, teachers delivering homework and assignments, and informing about course resources and connections.

Instructors joining academic groups linked to their colleges, departments, or classes and carrying out group work by exchanging assignments, tasks, ideas, and so on are examples of collaboration. Exchanging digital resources, photographs, audio materials, animated videos, resources, and documents are an example of resource and material sharing activities.

\subsubsection{Social Networking Sites (SNSs) Use in Education}

Over the last 30 years, computer-mediated social networks have grown exponentially. SNSs such as Twitter, MySpace, and Facebook, which have hundreds of millions of users, are examples of social software today (Lambic, 2016). SNSs are virtual spaces where people who share common interests, share images, and discuss ideas (Mao, 2014). Because of the large number of options provided by these sites, the functioning of SNSs is heavily reliant on users' preferences. More than $90 \%$ of university students in the United States use SNSs (Junco, 2012b). The vast majority of users stated that they use social media sites every day (Lambic, 2016).

The widespread use of SNSs by students of various ages demonstrates the potential of SNSs in education (Al-rahmi et al., 2014). SNSs could be used in education to support student communication, information gathering, and participation in collaborative learning networks based on shared interests and affinities rather than just the immediate learning environment (Kitsantas et al., 2016).

However, there are also some negative effects of SNSs. Students reported social networking can be addictive, distracting, and harm social relationships, mental health, and work completion (Kitsantas et al., 2016). To use SNSs as practical learning tools, complex efforts in design, scaffolding, and interacting with students are required (Lambic, 2016).

\subsubsection{Facebook Groups as a Learning Tool}

The use of Facebook groups as a learning management system (LMS) is one of the potential benefits of Facebook in education. The essential functions of an LMS can be easily implemented. Students are usually happy when they use Facebook groups for educational purposes (Wang et al., 2012). This type of application allows for a shift in focus from content-based learning to process-based learning (Lambic, 2016). It also makes the transition from passive to 
active learning much more accessible. Students believe that Facebook allows them to become more acquainted with their classmates, feel valued participants, learn more course material (Barczyk and Duncan, 2013), and share information more effectively, it is preferred as a learning aid over eLearning commons (such as Blackboard or Moodle).

Students may benefit from using Facebook for educational purposes in a variety of ways, including identifying and locating learning materials, assisting friends with questions, connecting with others, sharing lecture and study notes, receiving notification regarding the course, and increasing interaction with other students and teachers (Kitsantas et al., 2016).

\subsection{Theoretical Model and Hypotheses}

This study anchored on Cruz and Carvalho's model for information communication technology (ICT) integration for collaborative learning is presented below (Fig. 1). It includes the constructivist, engagement, and motivation theory (Cruz and Carvalho, 2005). This theoretical framework discusses how information, communication, and collaboration tools can be applied in the learning process. This framework shows that students with online collaboration could accomplish the learning objectives of the constructivist theory. Cruz and Carvalho (2005) asserted that in a social constructivist environment, learners with collaboration can develop critical thinking, negotiation, interpersonal and cooperative skills by experiencing other group member's viewpoints and expanding their knowledge.

The constructivist theory has been described as a studentcentered learning paradigm (Bruner, 1996; Vygotsky, 1978). Instructional models based on the social constructivist perspective stress the need for collaboration among learners and with practitioners. A society's practical knowledge is situated in relation to practitioners, their practice, and the social organization and political economy of communities of practice. For this reason, learning should involve such knowledge and practice (Lave et al., 1991; Gredler, 1997). Driscoll (2005) conducted research based on constructing a theory in three parts: the condition of instruction, methods of instruction and learning goals. Collaborative learning is one of these instructional techniques.

Similarly, attention, relevance, confidence, and satisfaction (ARCS) (Keller, 1983; Keller, 1984; Keller, 1988) model is a problem-solving approach to deal with planning the persuasive aspects of learning conditions to stimulate and sustain students' inspiration to learn. On the contrary, engagement theory is a framework for technologybased teaching and learning; Miliszewska and Horwood (2006) idea is that students should be meaningfully occupied with learning exercises through interaction with others and beneficial undertakings. The effective integration of ICT tools into the learning process could improve the learning and teaching process (Khan, 2005). Facebook as a Web 2.0 and ICT tool has different qualities that fit well with social constructivist learning (Bryant, 2007).

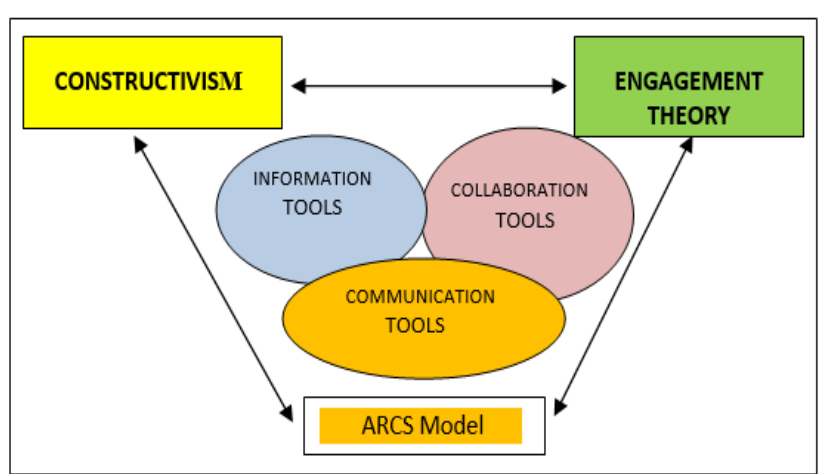

Fig. 1. Cruz and Carvalho (2005) model

The theoretical framework of this study is presented in Fig. 2. Three variables including the Facebook groups use (FGU), ease of use (EU), and usefulness of Facebook groups (UF) are the factors that influence students' academic performance (AP). We put forward the three hypotheses below:

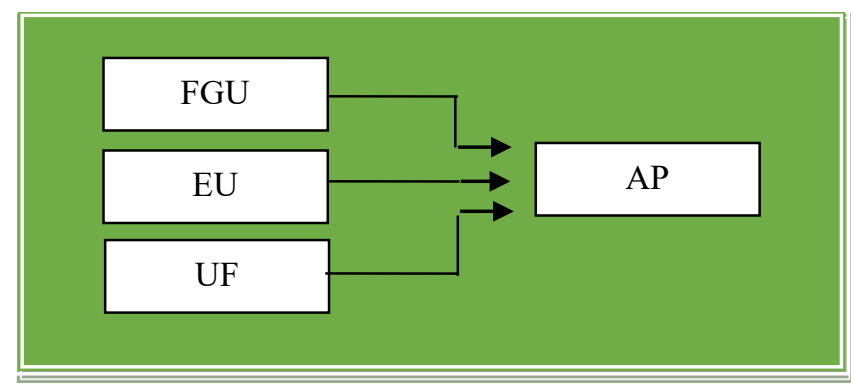

Fig. 2. Schematic presentation of the factors of student use of Facebook groups

Hypothesis 1 . There is a positive influence between the Facebook groups' use with ease of use, usefulness of Facebook groups, and academic performance.

Hypothesis 2. Facebook groups use as a support for academic learning has significant impact on student's academic performance.

Hypothesis 3. There is a significant relationship of Facebook groups use with ease of use, usefulness, and academic performance.

\section{METHODS}

\subsection{Respondents and Procedures}

The respondents of the study comprising of 1,056 college students were arbitrarily chosen from Technological State Universities and Colleges (SUCs) in Region VIII, Philippines. There were only 590 retrieved questionnaires from the 708 samples. The survey questionnaires were administered in printed copies last March 2019. Two sets of instruments were utilized in particular: the interview schedule for the qualitative part and the survey questionnaire for the quantitative analysis. Respondents 
were voluntarily consented to give answers to the questionnaires. Subsequently, no monetary remuneration or incentives were given. The data provided by the participants and the schools recognized in the study were treated with utmost secrecy.

\subsection{Instruments}

The instruments were designed from the survey questionnaires utilized by Nyuyen et al. (2013); Selpa (2017); Liz et al. (2016); Orioque (2020); Kitchakarn (2013). The content of which were thoroughly revised to fit them to the study. The instruments comprise of four sections, as follows: (1) Instruments of Facebook groups use. The objective of getting data about the respondents' Facebook groups use along with resources, projects/assignments, collaboration/group discussion, and the quantity of hours spent in a week by the respondents in using the Facebook groups. (2) Instruments of usefulness of Facebook groups for academic purposes. It utilizes a five-point scale which was coded as follows: 1-strongly disagree; 2-disagree; 3neutral; 4-agree; and 5-strongly agree; (3) Instruments of students' level of academic performance of the subject use in Facebook groups. The ask questions to determine the level of undergraduates' academic performance of the subject use in Facebook groups; (4) Instruments of ease of use. It utilizes a five-point scale which was coded as follows: 1-excellent; 2-very great; 3-good; 4-poor; 5-very poor.

\section{RESULTS}

\subsection{Descriptive Analysis of Facebook Groups Use} and Academic Performance

The descriptive analysis of students Facebook groups use and academic performance is presented in Table 1 that of the three items (project/assignment, collaboration, and elearning resources), they had similar levels of hours spent in getting to Facebook groups use which were at 1.0 - 4.9 hours of the week however they spent more hours doing their academic related task considering it had the highest mean in hours.

Results suggest that the respondents spent more hours asking questions regarding their schoolmates' activities and assignments than collaborating with their group members. Additionally, the respondents got a low level mean in hours spent in a week, suggesting that they would allocate time also for their studies considering that they could still manage to do their scholarly work as shown by their satisfactory academic performance.

\subsection{Descriptive Analysis of Perceived Usefulness of Facebook Groups for Academic Learning}

It shows in Table 2 a positive participant's belief towards Facebook groups usability as it shows the overall weighted mean of 3.80 which indicates "useful."

These results were affirmed in the study of Wang et al. (2012) and Orioque (2020) by claiming that the use of Facebook as a peer-to-peer assessment, a process were college students assess their peers' work based on instructor-developed scale, resulted in better students' performance and satisfaction with their studies.

The descriptive analysis of perceived usefulness of Facebook groups demonstrated a positive participant's belief towards Facebook groups usability and it is confirmed with the qualitative results of the study that majority of the interviewees answered that "Facebook groups facilitated learning," among the reasons mentioned: it increases their (1) efficiency, (2) motivation, and (3) dissemination of information. The results showed that the student' perception of utilizing Facebook groups for academic purposes was significantly related to study habits and students' experience (Orioque, 2020).

Table 1. Facebook groups use and academic performance

\begin{tabular}{|c|c|c|c|c|}
\hline $\begin{array}{l}\text { Spent time } \\
\text { (per week) }\end{array}$ & Resources & $\begin{array}{l}\text { Project/ } \\
\text { Assign }\end{array}$ & $\begin{array}{l}\text { Collaboration/Grp. } \\
\text { discussion }\end{array}$ & $\begin{array}{l}\text { Qualitative } \\
\text { escription }\end{array}$ \\
\hline Less than 1 hour & .39 & .40 & .40 & Very low \\
\hline $1.0-4.9$ & 3.34 & 3.38 & 3.89 & Low \\
\hline $5.0-8.9$ & 6.4 & 6.59 & 7.33 & Moderate \\
\hline $9.0-12.9$ & 10.61 & 11.42 & 12.00 & High \\
\hline 13 hrs above & 14.20 & 14.73 & 15.02 & Very high \\
\hline Total & 3.74 & 3.82 & 3.79 & 3.78 (Low) \\
\hline Final rating & Frequency & $\%$ & Weighted Mean & Qualitative description \\
\hline $4.00-5.00$ & 1 & $0.17 \%$ & 5.0 & Conditional/Failure \\
\hline $2.21-3.00$ & 144 & $24.41 \%$ & 2.57 & Fairly satisfactory \\
\hline $1.81-2.20$ & 248 & $41.03 \%$ & 2.01 & Satisfactory \\
\hline $1.41-1.80$ & 149 & $25.25 \%$ & 1.65 & Very satisfactory \\
\hline $1.0-1.40$ & 48 & $8.14 \%$ & 1.22 & Outstanding \\
\hline Total & 590 & $100.00 \%$ & 1.99 & $\begin{array}{l}\text { Satisfactory (academic } \\
\text { performance) }\end{array}$ \\
\hline
\end{tabular}




\section{International Journal of Applied Science and Engineering}

Orioque et al., International Journal of Applied Science and Engineering, 18(4), 2021021

Table 2. Perceived usefulness of Facebook groups for academic learning

\begin{tabular}{|c|c|c|}
\hline Statement & $\begin{array}{l}\text { Weighted } \\
\text { mean }\end{array}$ & $\begin{array}{l}\text { Qualitative } \\
\text { description }\end{array}$ \\
\hline $\begin{array}{l}\text { 1. Facebook is an effective instrument supporting communication and the } \\
\text { exchange of school-related data. }\end{array}$ & 4.09 & Agree \\
\hline $\begin{array}{l}\text { 2. Facebook allows and enhances collaboration beyond the school } \\
\text { community for academic and professional development. }\end{array}$ & 3.81 & Agree \\
\hline $\begin{array}{l}\text { 3. Facebook is exceptionally helpful in accomplishing work and promoting } \\
\text { collaboration among group members. }\end{array}$ & 3.95 & Agree \\
\hline $\begin{array}{l}\text { 4. Facebook helps users get to and share rich, interactive resources } \\
\text { effectively, which improves the learning experience. (Interactive media: } \\
\text { the utilization of text, designs, animation, pictures, video, and sound to } \\
\text { present information.) }\end{array}$ & 3.78 & Agree \\
\hline 5. Using Facebook is helpful for my own learning experience. & 3.55 & Agree \\
\hline $\begin{array}{l}\text { 6. Facebook can be a powerful way to assist informal learning (discovering } \\
\text { that is driven by personal interests/needs through everyday encounters or } \\
\text { collaboration with other people/resources). }\end{array}$ & 3.62 & Agree \\
\hline $\begin{array}{l}\text { 7. Facebook is an excellent place to stay in touch with other students in the } \\
\text { class. }\end{array}$ & 3.84 & Agree \\
\hline $\begin{array}{l}\text { 8. Facebook is an excellent place to request help with schoolwork } \\
\text { tasks. }\end{array}$ & 3.81 & Agree \\
\hline 9. Facebook is an excellent place to talk different topics with colleagues. & 3.70 & Agree \\
\hline $\begin{array}{l}\text { 10. Facebook is a good place to connect links to resources given by the } \\
\text { instructor. }\end{array}$ & 3.82 & Agree \\
\hline Overall weighted mean & 3.80 & $\begin{array}{l}\text { Agree } \\
\text { (Useful) }\end{array}$ \\
\hline
\end{tabular}

Table 3. Regression analysis on Facebook groups use and academic performance

\begin{tabular}{|c|c|c|c|c|c|}
\hline Model & \multicolumn{2}{|c|}{ Unstandardized coefficients } & \multirow{2}{*}{$\begin{array}{c}\text { Standardized coefficients } \\
\text { Beta }\end{array}$} & \multirow[t]{2}{*}{$\mathrm{T}$} & \multirow[t]{2}{*}{ Sig. } \\
\hline & $\mathrm{B}$ & Std. Error & & & \\
\hline \multicolumn{6}{|c|}{$\begin{array}{c}1 \\
\text { (Constant) }\end{array}$} \\
\hline FGU & 1.958 & .022 & & 89.186 & .000 \\
\hline $\mathrm{AP}$ & .009 & .002 & .153 & 3.742 & .000 \\
\hline a. I & it Variable & & & & \\
\hline
\end{tabular}

\subsection{Regression Analysis on Facebook Groups Use and Academic Performance}

Table 3 found a significant relationship $\beta=.153$ at $p<$ 0.05 (significant path), indicating that the Facebook groups use significantly impacts the academic performance. The finding was parallel with the results of Moghavvemi et al. (2017) that the relationship between the use of Facebook groups and academic performance is positive and significant $(\beta=0.232$, at $\mathrm{p}<0.022)$. Furthermore, Negussie and Ketema (2014) also asserted a substantial relationship between times spent on social networks such as Facebook with students' grade point average (GPA).

\subsection{Correlation Aanalysis}

Table 4 reflects the correlation coefficients among respondents' Facebook groups use, usefulness, ease of use, and academic performance presented ranging from 0.05 to .89 , that is, from negligible to little (weak) correlations.
It can be observed in Table 4 that there is a positive relationship between respondents' Facebook groups use and ease of use of Facebook groups $[\mathrm{r}(588)=.67]$, Facebook groups use and usefulness of Facebook groups [r(588) $=.65]$, Facebook groups use and academic performance $[\mathrm{r}(588)=.15]$. Based on the results presented, it can be observed that the Facebook groups use was positively correlated to the ease of use, usefulness, and academic performance.

\subsection{Discussion}

It revealed three key findings of the study with regards to student use of Facebook groups use as a support for academic learning.

First, according to the results presented, the perceived usefulness of Facebook groups for academic learning shows in Table 2 a positive participants' belief towards Facebook groups usability. It shows the overall weighted mean of 3.80 which indicates "useful". It affirms Hypothesis 1 students 
Orioque et al., International Journal of Applied Science and Engineering, 18(4), 2021021

Table 4. Correlation analysis of the four factors of the study

\begin{tabular}{llcccc}
\hline \multicolumn{1}{c}{ Variables } & 1 & 2 & 3 & Academic performance \\
\hline 1. & The Facebook groups use & - & $.67^{* *}$ & $.65^{* *}$ & $.15^{* *}$ \\
2. & Ease of use of Facebook groups & & - & $.89^{* *}$ & .05 \\
3. & Usefulness of Facebook groups & & & - & .08 \\
\hline
\end{tabular}

Note. $*=$ p-value $\leq .05, * *=$ p-value $\leq .01$

show comfortable utilizing Facebook groups as a learning tool, particularly in their group discussion. Thus, it is concluded that the comfort of utilizing the Facebook enabled the students to see its significance. The results confirmed by the previous studies that ease of use had significant influence on perceived usefulness (Adlawan and Smedley, 2013). Additionally, the student's academic performance shows their good study habits, as revealed in Table 1. The results recommend that utilizing Facebook groups as a learning tool gives a motivating learning environment and it is confirmed with the qualitative results of the study that majority of the interviewees answered that "Facebook groups facilitated learning," among the reasons mentioned: it increases their (1) efficiency, (2) motivation, and (3) dissemination of information. The results showed that the student' perception of utilizing Facebook groups for academic purposes was significantly related to study habits and students experience (Orioque, 2020).

Second, the regression analysis found in Table 3 suggest a significant relationship between Facebook groups use and academic performance, hence Hypothesis 2 was accepted. Facebook groups use as a support for academic learning have significant impact on academic performance. The finding was confirmed by Moghavvemi et al. (2017) study that the correlation between Facebook groups use and academic performance is positive and significant. As Helou and Rahim (2014) stated, in the research, most of the respondents agreed that online networking sites had a significant impact on their academic performance. On the other hand, there is a study indicating lower academic performance of students who use Facebook (Junco, 2012a; Kirschner and Karpinski, 2010). However, Facebook and other social media platform are not the only potential distractors from studying (socializations, video games, internet, television, sports, etc.), so the question arises whether students who do not participate in only one potentially distracting activity will achieve better grades than other (Lambic, 2016).

Third, in the correlation analysis found in Table 4 indicates a positive correlation between the Facebook groups use with the ease of use, usefulness, and academic performance. This affirms Hypothesis 3 that there is a significant relationship of Facebook groups' use with ease of use, usefulness and academic performance. The findings indicate that students felt comfortable when social media was used as learning tool in the course. As a result, they found it rather easy to communicate with one another on Facebook.

\section{CONCLUSION}

This study analyzed and explored the relations of Facebook groups' use, ease, usefulness, and academic performance. Based on the results, Facebook groups use significantly impact respondents' academic performance. It is confirmed with the study of Sanchez et al. (2014) that Facebook groups' adoption has significant influence on the educational usage of Facebook groups and also with the findings of Lambic (2016) that there is a positive correlation between the frequency of use of Facebook groups as a learning aid and actual number of points attained by the student during the course. Further, even though Facebook was not initially intended for educational purposes but it has a great potential to improve the learning experience; as Lambic (2016) asserted, the use of Facebook for general purposes does not negatively affect the students' academic performance. Finally, it can be concluded that Facebook groups are a helpful tool that supports the students' academic learning. Directions for future research are suggested. First, investigating other persuasive factors on Facebook use could be significant; second, it would likewise be intriguing to lead future studies with students from various countries to determine if differences in sociocultural settings affect Facebook use for academic learning.

\section{ACKNOWLEDGMENT}

This research wishes to express sincere gratitude to the following, without whom, this paper would not become a reality. First and foremost, praises and thanks to God, the Almighty, to Dr. Norberto C. Olavides, Dr. Antonia D. Mendoza, Dr. Rose A. Arceño, Josie Quiban, and most especially to my husband, Edgar Orioque.

\section{REFERENCES}

Abecia, D., Samong, M., Abella, L., Baldomero, F., Tamayo, A., Gabronino, R. 2014. Measuring happiness of university students. American Journal of Social Sciences, $2,43-48$.

Adlawan, A., Smedley, J. 2013. Exploring students' acceptance of e-learning using technology acceptance model in Jordanian Universities. International Journal of Education and Development using Information and Communication Technology, 9, 4-18. 
Ainin, S., Naqsbandi, N.M., Moghavvemi, S., Tamayo, A., Gabronino, R. 2015. Facebook usage, socialization and academic performance. Computers and Education, 64-73. doi:10.1016/j.compedu.2014.12.018

Al-rahmi, W.M., Othman, M.S., Musa, M.A. 2014. Social media through collaborative learning in Malaysian higher education. Asian Social Science, 10, 210-221.

Barczyk, C.C., Duncan, D.G. 2013. Facebook in higher education courses: an analysis of students' attitudes, community of practice, and classroom community, International Business and Management, 6, 1-11.

Bruner, J.S. 1996. Toward a theory of instruction. Cambridge Massachusets: Belknap Press.

Bryant, O. 2007. The challenge of adaptive leadership, in Emerging Technologies for Learning. British Educational Communications and Technology Agency (BECTA), 2, 9-22.

Cruz, S., Carvalho, A.M. 2005. Modelo ITIC: Uma possibilidad epara a integracao curricular das TIC naescolarida de basica. I Encontro International TIC e Educacao, 381-388.

Dahlstrom, E., de Boor, T., Grunwald, P., Vockley, M. 2011. ECAR: National study of undergraduate students and information technology. Retrieved from https://net.educause.edu/ir/library/pdf/ERS1103/ERS110 3W.pdf.

Dickie, V.A., Meier, H. 2015. The Facebook tutor: networking education. Ubiquitous Learning, 8, 1-12.

Driscoll, M. 2005. Constructivism. Psychology of Learning for Instruction, Toronto, USA, Pearson, 384-407.

Goertler, S. 2009. Using computer-mediated communication (CMC) in language teaching. Die Unterrichpraxis/Teaching German, 74-84. doi:10.1111/j.1756-1221.2009.00038

Gredler, M.E. 1997. Learning and instruction: theory into practice ( $3^{\text {rd }}$ ed.). Science and Education. 4, 1-20.

Helou, A.M., Rahim, N.Z. 2014. The influence of social networking on students' academic performance in Malaysia. International Journal of Electronic Commerce Studies, 5, 247-254. doi:10.79.3/ijecs. 1114

Junco, R. 2012a. The relationship between frequency of Facebook use, participation in Facebook activities, and student engagement. Computers and Education, 58, 162171.

Junco, R. 2012b. Too much face and not enough books: the relationship between multiple indices of Facebook use, and academic performance. Computers in Human Behavior, 28, 187-198.

Junco, R. 2015. Student class standing, Facebook and academic performance. Journal of Applied Development Psychology. 36, 18-29.

Keller, J. 1983. Motivational design of instructions. Instructional design theories and models: An overview of their current status, Ed. Hilldale, New Jersey, USA, Lawrence Erlbaum Associates, 383-436.

Keller, J. 1984. The use of the ARCS model of motivation in teacher training. Aspects of Educational Technology,
Staff Development and Career updating, K.E. Shaw, Ed, Londod, UK, Kogan Page, XVII, 140-145.

Keller, J.M. 1988. Motivational design. Encyclopedia of educational media, communications, and technology, 2nd Edition, R, Mc Aleese, D. Unwin, Eds, Westport, Connecticut, USA, Greenwood Press.

Khan, O. 2005. The challenge of adaptive leadership. Leader to leader. doi:10.1002/ltl.154

Kirschner, P.A., Karpinski, A.C. 2010. Facebook and academic performance. Computers in Human Behavior, 26, 1237-1245. http://dx.doi.org/10.1016/ j.chb.2010.03.024.

Kitchakarn, O. 2013. Peer feedback through blogs: An effective tool for improving students writing abilities. Turkish Online Journal of Distance Education, 14, 152164. doi:10.17718/TOJDE.94937

Kitsantas, A., Dabbagh, N., Chirinos, D.S., Fake, H. 2016. College students' perceptions of positive and negative effects of social networking. Social Networking and Education. 225-238.

Lambic, D. 2016. Correlation between Facebook use for educational purposes and academic performance of students. Computers in Human Behavior, 61, 313-320.

Lave, J., Wenger E. 1991. Situated learning: Legitimate peripheral participation. Cambridge, UK: Cambridge University Press.

Liz, A., Feller, J., Nagle, T. 2016. Social media as a support for learning in universities: An empirical study of Facebook Groups. Journal of Decision, 25, 35-49. doi:10.1080/12460125.2016.1187421.

Manasijevic, D., Zivkovic, D., Arsic, S., Milosevic, I. 2016. Exploring students' purposes of usage and educational usage of Facebook, Computers in Human Behavior. 60, 441-450. www.elsevier.com/locate/comphumbeh.

Mao, J. 2014. Social media for learning: a mixed methods study on high school students' technology affordances and perspectives. Computers in Human Behavior, 33, 213-223.

Miliszewska, I., Horwood, J. 2006. Engagement theory: A Universal Paradigm?,SIGCSE'06: Proceedings of the $37^{\text {th }}$ SIGCSE technical symposium on Computer science education. 158-162. https://doi.org/10.1145/1121 341.1 121392

Moghavvemi, S., Sulaiman, A., Aziz, A.A., Wai, S. 2017. The impact of Facebook usage on academic performance. International Conference on Research and Innovation in Information Systems (ICRIIS), 1-5. Langkawi, Malaysia. doi:10.1109/ICRIIS.2017.8002518

Nyuyen, N.P., Yan, G., Thai, M.T. 2013. Analysis of misinformation containment in online social networks. Computer Networks, 57, 2133-2146. doi:10.1016/j.comnet.2013.04.002

Orioque, J.A. 2020. Facebook use as a support for academic learning among technological state universities and colleges in region 8. Journal of Innovative Technology Convergence, ISSN No:2704-4440, 2, 9-16. 
Qureshi, I.A., Raza, H., Whitty, M. 2014. Facebook as elearning tool for higher education institutes. Knowledge Management and E-learning, 6, 440-448.

Sanchez, R.A., Cortijo, V., Javed, U. 2014. Students perceptions on Facebook for academic purposes. Computers and Education, 138-149. doi:10.1016/j.compedu.2013.08012

Selpa, H.D. 2017. Usage of social networking sites and academic performance: Basis for management intervention. Palompon, Leyte, Philippines: Palompon Institute of Technology.

Statista, 2018. Numer of monthly active Facebook users worldwide as of 1 st quarter 2018 inmillions. Retrieved from statista.com: https://www.statista.com/ statistics/264810/numer-of-monthly-active-facebooksers-worldwide (accessed March 5, 2019).

Tracii, R., Xenos, S. 2011. Who uses Facebook? An investigation into the relationship between the big five, shyness, narcism, loneliness, and Facebook usage. Computers in Human Behavior, 27, 1658-1664. doi:10.1016/j.chb.2011

Vygotsky, L.S. 1978. Interaction between learning and development from mind in society, Cambridge, MA: Harvard University Press.

Wang, J.H., Quek, C., Yang, Y., Liu, M. 2012. Using the Facebook group as a Learning Management System: An Exploratory study. British Journal of Educational Technology, 43, 428-438.

Yang, Y., Wang, H.L., Woo, C.L., Quek, C.L. 2011. Using Facebook for teaching and learning: A review of the literature. International Journal for Continuing Engineering Education and Life-Long Learning, 21, 7286. doi:10.1504/IJCEELL.2011.039695 